Portland State University

PDXScholar

Spring 2013

\title{
Assessing Through Reflection: Valuing our Wisdom and Trusting our Gut
}

Robert Schroeder

Portland State University, schroedr@pdx.edu

Follow this and additional works at: https://pdxscholar.library.pdx.edu/ulib_fac

Part of the Library and Information Science Commons

Let us know how access to this document benefits you.

Citation Details

Schroeder, R. (2013). Assessing Through Reflection: Valuing our Wisdom and Trusting our Gut" published in OLA Quarterly, Vol. 19, No. 1.

This Article is brought to you for free and open access. It has been accepted for inclusion in Library Faculty Publications and Presentations by an authorized administrator of PDXScholar. Please contact us if we can make this document more accessible: pdxscholar@pdx.edu. 


\section{Assessing Through Reflection: Valuing our Wisdom and Trusting our Gut}

\author{
by Robert Schroeder \\ Education and University \\ Studies Librarian \& Coordinator \\ of Library GenEd Instruction, \\ Associate Professor, \\ Portland State University
}

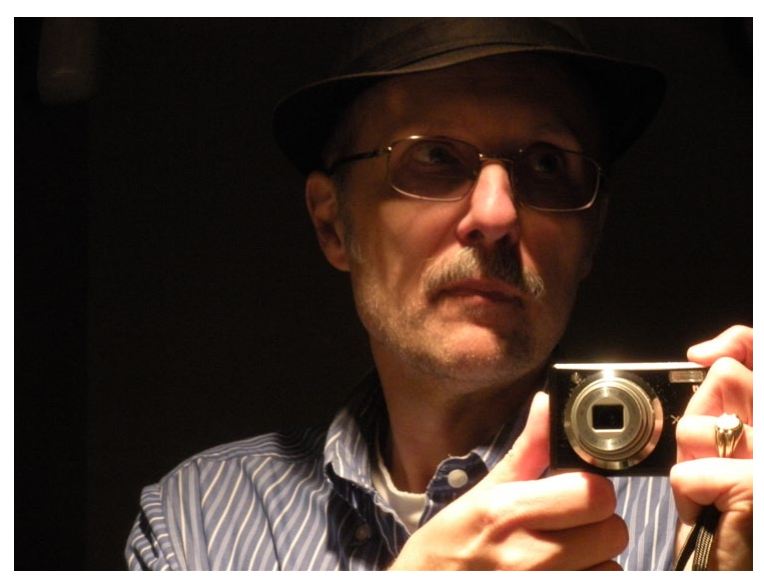

\{First gentle reader I must beg your pardon for the purplish-hued prose style in which the following essay is penned. When I searched about for proximate causes I could only rally in my defense the recent viewing of seven episodes of Downton Abbey. For best effect I recommend one imagine that the Dowager Countess and Carson are alternately reading aloud the following paragraphs. Perhaps as part of a tableau vivant on Boxing Day?\}

Assess — from the Latin assidére, to sit by.

There are many ways to assess our effectiveness when it comes to the teaching and learning of information literacy. And there are many times when student surveys, focus groups, or other qualitative or quantitative means or measurement make perfect sense. But I would like to suggest that there are other ways to get a handle on how well we are teaching and how well students are learning, ways that are equally as useful and valid as these other measures, and ones that we can cultivate within ourselves. Reflection and self-cultivation, holding ourselves up as mirrors to our classrooms can often be a most useful and expedient standard.

Most librarians, by their bookish nature (if I may be so bold), are inveterate readers and researchers. And we read about issues that affect our classrooms - learning styles, teaching strategies, the digital divide, and the latest technology du jour. Day by day, and by leaps and bounds our knowledge of classroom techniques and student learning grows, and I would venture that our concern for student learning and our passion for our students' success oftentimes acts as a catalyst to this knowledge and, like the alchemy of old, turns our understanding into wisdom.

I submit that we are wise in many ways; we need only to reflect and realize this fact. And our wisdom reveals itself in the very fact that we do strive to learn about learning, and it shows itself in our earnest desire to improve. But what use do we make of this great virtue, or do we squander it away? The sad fact, as I see it, is that we frequently ignore this treasure at our fingertips. When confronted with questions about how our students are progressing, instead of relying on our hard-researched knowledge, we immediately start to devise a new survey or focus group to see how our students measure up.

I will give a hypothetical example. Say I am newly teaching a group of students who come from Saudi Arabia, and who have learned English as their second language. Challenges may be arising that I have never experienced before. So I read a half a score of articles on the subject of teaching information literacy to ESL students, and a passel of the articles even mention some cultural competencies to help with teaching students from Saudi Arabia. If I make what I see as appropriate adjustments to my teaching based on the suggestions from the articles, and reflect upon the teaching and learning as it happens, might that not be assessment enough? 
This is not to say that no assessment is happening, but more correctly that the assessment is rather more subjective, anecdotal, and internal than what most often is meant by this term. I may see that student involvement has increased just by the hubbub in the classroom, or perhaps the groups seem now to be progressing more smoothly and quickly through the exercises. Checking in with teaching faculty who may be present, either at the time of the class or by a quick e-mail later, may also be an easy way to ascertain if the learning goals are being met. But instead of considering my sole option for assessment to be a full-blown survey of these students, I am suggesting that we pause to acknowledge the value of our wisdom.

This wisdom consists of a combination of our focused search for, and recovery of appropriate and tested models that we rely upon in augmenting our lessons, and our earnest and focused intentions to create more effective learning situations for our students. If we value our wisdom, and the collective wisdom of the librarians who have done the studies upon which we rely, then I would ask do we need to nearly always feel compelled to do a full-blown quantitative assessment? Rather we might take a breath, and realize that yes, all of our study was for a good reason, and yes we are smart enough to see our students confirming the results of those many other studies upon which we based our class.

At this juncture I would hazard to say that we must not only raise the value we place on our wisdom, but we must also begin to trust our gut. This trusting our gut will color our instruction more an art than a science, but I would estimate this tint not to be a muddied shade, but rather a dazzling hue that spreads upon the canvas of our pedagogy. If our focus is clear and our attention is on our students in the classroom as they learn, then we will be learning with them. What we will be learning will be how to better teach our students — by sitting beside them, and reflecting, they will teach us how to teach them.

\section{Coda}

Here I must give credit to two sources of inspiration for this essay. One is the ever-entertaining and eternally enlightening Dale Vidmar of Southern Oregon University. He has worked many years developing his model of reflective peer coaching, and has written an excellent article on it titled, "Reflective Peer Coaching: Crafting Collaborative Self-Assessment in Teaching. While Dale's focus is on developing pairs of librarians as peer coaches, I sense that his ultimate goal might be for us to internalize this reflection, so that we can in a way be peer coaches unto ourselves. The other educator I must credit is Paulo Freire. He opened my eyes to a fact that should come as no surprise to most librarians, as the collaborative nature our work at the reference desk embodies it. He says that both the "student" and the "teacher" are always both teaching and learning, or as he put it in Pedagogy of the Oppressed, "through dialogue, the teacher-of-the-students and the students-of-the-teacher cease to exist and a new term emerges: teacher-student with students-teachers" (Freire, 2000, p. 80).

\section{Works Cited}

Freire, P. (2000). Pedagogy of the oppressed. New York: Continuum.

\section{0}

